\title{
Some Traditional Medicinal Plants of North Region from Puebla, Mexico: Uses and Potential Pharmacological Activity of Rumex spp.
}

\author{
Jerezano Alberto V ${ }^{1 *}$, Pazos Diana del $C^{2 *}$ Ríos Saúl $A^{3}$, Tepancal-Gomez $E^{4}$, Salas-Mendoza $E^{4}$, Villanueva $L^{4}$, Perez-Perez $I^{5}$, Murrieta M ${ }^{5}$, \\ Delgado Francisco $\mathbf{R}^{6}$, Tamariz $\mathbf{J}^{6}$ and Garduño Leticia $\mathbf{S}^{7}$ \\ ${ }^{1}$ School Stomatology, Benemérita Universidad Autónoma de Puebla, Arias y Boulevar S/N, Col El Carmen, C.P. 73820. Teziutlán, Puebla, Mexico \\ ${ }^{2}$ Department of Investigation and Graduate Studies, Instituto Tecnológico Superior de Teziutlán, Fracción I y II Aire Libre S/N. C.P 73960, Teziutlán, Puebla, México \\ ${ }^{3}$ School Medicine, Benemérita Universidad Autónoma de Puebla, Arias y Boulevar S/N, Col El Carmen, C.P. 73820. Teziutlán, Puebla, Mexico \\ ${ }^{4}$ School Psychology, Benemérita Universidad Autónoma de Puebla, Arias y Boulevar S/N, Col El Carmen, C.P. 73820. Teziutlán, Puebla, Mexico \\ ${ }^{5}$ School Nursing, Benemérita Universidad Autónoma de Puebla, Arias y Boulevar S/N, Col El Carmen, C.P. 73820. Teziutlán, Puebla, Mexico \\ ${ }^{6}$ Department of Organic Chemistry, ENCB-IPN, Prol. Carpio y Plan de Ayala, 11340, México DF, México \\ ${ }^{7}$ Department of Pharmacy and Preclinical Toxicology, ENCB-IPN, México DF, México
}

\begin{abstract}
This paper, based on the traditional knowledge and research, aims to provide an overview of the current state of local and traditional medical uses, pharmacological potential activities, toxicity and safety of some medicinal plants from north region of Puebla State, Mexico. The information about use medicinal plants was obtained by a poll the therapists from Traditional Medicinal Hospitals from Ayotoxco, Xalacapan and local market of Teziutlán. The information obtained of the empiric knowledge from therapists of Traditional Medicine about of extracts, whole and parts of some plants, like are used on the treatment of several health disorders common in the north region of state Puebla, such as pains, infections, fever, constipation, diahorrea and periodontals disorders is discusses. Rumex spp widely distributed as wild plant in the northern region of Puebla, consumed in salad, presents a variety of applications to treat oral diseases and antipyretic as a poultice, has aroused great interest to be studied by our research group. Despite its historical and cultural importance, the "traditional" use of plants has decreased.
\end{abstract}

Keywords: Rumex spp.; Traditional herbal medicine; Medicinal plants; Extracts; Antipyretic; Anti-inflammatory; Therapists

\section{Introduction}

The plant kingdom has been the main source of medicine of humanity for hundreds of years and there is a vast accumulation of knowledge inherited for centuries. Scientific interest in medicinal plants in the past 40 years has led to the discovery of new molecules and active ingredients derived therefrom that give answers to very serious health disorders. Many plants and parts thereof, usually dry, still used worldwide as home remedies or as ingredients in herbicides, spiritual therapies, fermented drinks, poultices, ointments by therapists of the Traditional Herbal Medicine (THM) by their medicinal properties [1-5]. Not surprisingly, that these products are first or second option in treatment of important diseases [1]. Examples, soy isoflavones (Glycine max), [6] for menopause and climacteric; silymarin of milk thistle (Sylybus marianus) as hepatoprotective $[7,8]$ taxol from yew (Taxus baccata), for different types of cancer; $[9,10]$ galantamine the Galanto (Galanthus nivalis) for Alzheimer's disease; [11] extracts of ivy (Hedera helix), as antitussive and expectorant [12]; the partenólids of migranella (Tanacetum parthenium), in cases of headaches and migraines; [13] flavonoids ginkgo (Ginkgo biloba) in cognitive disorders [14]. In Mexico 7,000 species are used as medicinal plants. Traditional Herbal Medicine of the State of Puebla is still unfinished and information scattered on few works, papers, magazines, etc., both local, national and international not just give us a general idea of what this treasure is supposed of the nature $[15,16]$. This paper is not intended to address all Mexican medicinal flora, if not devoted to the north region of State Puebla and especially the flora Teziutlán. We hypothesize that the exploration of research approaches over time proven traditional herbal medicine could lead to new areas of research of medicinal plants. Our perspectives include a research of the practice of the same Herbal Medicine in the north region of Teziutlán Puebla. Though this discussion must include some examples of herbs from Teziutlán, Puebla, Mexico only, the focus of our discussion underscores traditional herbal medicine strategies that can be used for the community and the Family and Community Medicine program,
School Medicine, and Stomathology program, School Estomatology, Complejo Universitario de la Salud (CUS), Benemerita Universidad Autónoma de Puebla (BUAP). We have listed some traditional medicinal plants, with general approach about traditional practice of herbal therapy, and pharmacological potential, and how to use, mainly Rumex spp (Lengua de Vaca).

\section{Materials and Methods}

\section{Study area}

Teziutlan is located north of the State of Puebla, in the northern part of Neovolcanic, almost bordering the state of Veracruz, between parallels $19^{\circ} 46^{\prime}$ and $19^{\circ} 58^{\prime}$ north latitude; meridians $97^{\circ} 19^{\prime}$ and $97^{\circ} 25^{\prime}$ west longitude; altitude between 700 and $2400 \mathrm{~m}$ (Figure 1). Teziutlán bordered on the north by the municipalities of Hueyapan and Hueytamalco; east with the municipalities of Hueytamalco and Xiutetelco; south with the municipalities of Xiutetelco and Chignautla; west with the municipalities of Chignautla and Hueyapan. It occupies $0.3 \%$ of the state's area $92518 \mathrm{~km}^{2}$. It has 33 locations and a total population of 92,246 inhabitants, with Nahuatl and Totonac main dialects [17]. Within this area we find the Cuenca called "La Gran Caldera de Teziutlán" [18]. The predominant soil types in this area are

*Corresponding authors: Jerezano Alberto VD, School Stomatology, BUAP, Arias y Bulevar S/N, Col El Carmen, C.P. 73820, Teziutlán, Puebla, México, Tel: 2224269508; E-mail: albertovjerezano@gmail.com

Pazos Diana del CG, Department of Investigatión and Graduate Studies, Instituto Tecnológico Superior de Teziutlán, Fracción I y II Aire Libre S/N. C.P 73960. Teziutlán, Puebla, México, Tel: 5540806082; E-mail: dianadelcpg@yahoo.com

Received May 15, 2016; Accepted April 01, 2016; Published April 06, 2016

Citation: Jerezano Alberto VD, Ríos Saúl A, Tepancal-Gomez E, Salas-Mendosa E, Villanueva L, et al. (2016) Some Traditional Medicinal Plants of North Region from Puebla, Mexico: Uses and Potential Pharmacological Activity of Rumex spp. Nat Prod Chem Res 4: 223. doi:10.4172/2329-6836.1000223

Copyright: (c) 2016 Jerezano Alberto VD, et al. This is an open-access article distributed under the terms of the Creative Commons Attribution License, which permits unrestricted use, distribution, and reproduction in any medium, provided the original author and source are credited. 
Citation: Jerezano Alberto VD, Ríos Saúl A, Tepancal-Gomez E, Salas-Mendosa E, Villanueva L, et al. (2016) Some Traditional Medicinal Plants of North Region from Puebla, Mexico: Uses and Potential Pharmacological Activity of Rumex spp. Nat Prod Chem Res 4: 223. doi:10.4172/23296836.1000223

Page 2 of 7

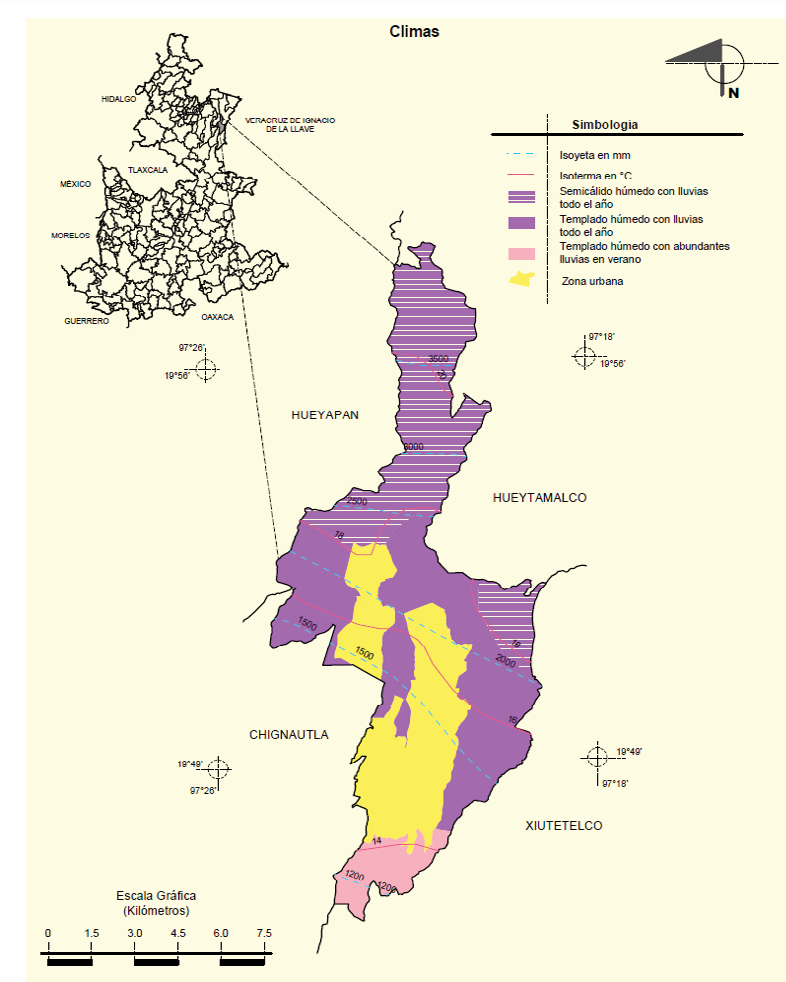

Figure 1: North region of the State Puebla, municipality of Teziutlan, Puebla, Mexico.

the andosols and regosols, which have a dark gray color on yellowish brown layer surface and in the deeper layers are rich in organic matter and have a high nutrient content.

\section{Weather}

Temperature range 12 to $22^{\circ} \mathrm{C}$, precipitation range $1100-3600 \mathrm{~mm}$, generally mild and humid with rains all year $(60 \%)$, semi wet with rain all year (31\%) and temperate humid with abundant rainfall summer (9\%). Its main locations are Teziutlán, Atoluca, San Juan Acateno, San Sebastian, Xoloateno, San Diego, Mexcalcuautla, Ixticpan, Cuaxoxpan [17].

\section{Medicinal plants (Traditional knowledge)}

Since the early days of discovery of the American continent, the way to cure the natives was praised, and sent to Spain remedies and therapeutic elements. In 1571, Felipe II sent to Francisco Hernandez make scientific expeditions, to carry out a well-documented in medicine and medicinal plants in the states of Mexico, Morelos, Puebla, Tlaxcala and Hidalgo. He collected all the information written in his work called History of the Plants, resulting in sixteen volumes of natural history of this land (1571-1576), containing a wealth of information about Mexican plants, and the description and drawings, giving special interest to medicinal plants [15].

The term of "healers" or "therapists traditional herbal medicine" originated in 2002 with the Program of Hospitals Integrals with Traditional Medicine (PHITM) in the State Puebla, whose main objective is to provide mixed health services and spaces where traditional medicine and allopathic medicine is developed in an intercultural framework. This mixed model of health care was applied at that time in five regions with high marginalization of the State of Puebla: Cuetzalan del Progreso, Ayotoxco, Huehuetla, Coxcatlán y
Tulcingo de Valle. Traditional medicine modules operate from then with hospital where traditional therapists provide care, recognized by their communities in different specialties such as are midwives, healers, bone setters, herbalists, etc., [19]. Therapists are recovering the knowledge of medicinal plants communities. Plants are grown and gather and then the therapists offer to people their knowledge and treatments at affordable prices.

\section{Results and Discussion}

During the period 2014-2015, interviews were conducted with different therapists around the northern region of the state of Puebla, such as the Hospitals of Traditional Medicine Herbal of Ayotoxco, Xalacapan and local markets Teziutlán. Healers or therapists are a group mostly women, urban and middle-aged-advanced, which have become in medicinal plants specialists with the explicit mission of "cure people with the use of medicinal plants." The information collected is presented in Table 1. The therapist uses the plants or preparation cold for a hot disease and plant or preparation warm for a cold disease.

The information obtained in Table 1 shows that Rumex spp. is used (one or two fresh leaves) as an antipyretic in the treatment of fever in children as poultice with animal fat, until get the dry leaves, suggesting that the nonpolar components are topically absorbed through the dermis, generating its antipyretic activity. Few reports of the use of Rumex as antipyretic agent, as in the case of traditional medicine in Turkey (Rumex patientia) [20]. There are some papers about the antipyretic properties of metabolites or hexane extracts compared with the form of use in the northern region of Puebla, this has aroused great interest to be studied by our research group. Farre et al. has reported anti-inflammatory properties of aqueous extracts from Rumex patientia [21], EtOAc extracts, anthraquinones and naphthalenes isolated from the root of Rumex nepalensis, show inhibitory effects, moderate to strong on COX-1 (compared with indomethacin as positive control) and COX-2 (compared with celecoxib) [22]. Analgesic activity is observed at high doses of methanolic extract of Rumex abyssunucus which has up to $70 \%$ protection in mice induced pain compared with aspirin and morphine as positive controls [23]. There are studies of antiviral activity of some molecules isolated from Rumex acetosa, [24,25] potential pharmacological activity to recurrent epidemics of influenza in Mexico.

Rumex spp. "Lengua de vaca" (Rumex spp) common in the region Teziutlán, belonging to the Polygonaceae family, is native to Europe, where it grows in almost any kind of soil, but prefers soils rich in iron and nearby courses water, ponds and wetlands and shady forest areas in general [26]

\section{Description taxonomy}

The plant is $50 \mathrm{~cm}$ tall, with perennials and woody roots some things that grow deep into the soil moist, and with an erect striated and single stem. The leaves are edible, oblong; 5 to $10 \mathrm{~cm}$ long, arrowshaped at its base, with wide and long lower leaves without petiole upper leaves, and often has a scarlet dye (Figure 2).

The flowers are delicious, reddish green male and female redder (such as $R$. acetosella), and appear especially in the months of June and July. As the flowers mature, they become purple. Mature seeds are bright and brown [26,27] Taxonomy. There are numerous species; the most remarkable are Rumex patientia, Rumex acetosa, Rumex scutatus, Rumex crispus, Rumex japonicus, Rumex dentatus, Rumex vesicarius, Rumex hymenosepalus, among other [27]. The Table 2 shows some reports on the traditional use of Rumex spp. and parts used. 
Citation: Jerezano Alberto VD, Ríos Saúl A, Tepancal-Gomez E, Salas-Mendosa E, Villanueva L, et al. (2016) Some Traditional Medicinal Plants of North Region from Puebla, Mexico: Uses and Potential Pharmacological Activity of Rumex spp. Nat Prod Chem Res 4: 223. doi:10.4172/23296836.1000223

Page 3 of 7

\begin{tabular}{|c|c|c|c|}
\hline Medicinal Plant & Scientific Name & How To Use & Traditional Use \\
\hline Albahaca & Ocimum basilicum L.(a) & $\begin{array}{l}\text { Make corsages and "ramear" all over the body as } \\
\text { sweep. Boil some leaves in water and take. Boil a } \\
\text { bunch and rinse after bathing. }\end{array}$ & $\begin{array}{l}\text { Clean spiritual. Stomachache. Postpartum } \\
\text { bath }\end{array}$ \\
\hline Alelía & Matthiola incana (a) & $\begin{array}{l}\text { Boil and let it sit in the water, use water to rinse the } \\
\text { end of the bath }\end{array}$ & Frightened children to bathe \\
\hline Árnica & $\begin{array}{l}\text { Tithonia diversifolia (Hemsley) A. } \\
\text { Gray (a) }\end{array}$ & $\begin{array}{l}\text { Alcoholic infusions of leaves to "rub". Poultices of } \\
\text { crushed leaves }\end{array}$ & Anti-inflammatory treatment \\
\hline Azomiate & Barkleyanthus salicifolius (a) & Tea leaves taken & Stomach ache \\
\hline Cancerina o hierba de angel & Hippocratea excelsa Kunth (a) & $\begin{array}{l}\text { The whole plant is boiled in } 1 \text { liter of water and when } \\
\text { no longer so hot wash affected area }\end{array}$ & Wounds \\
\hline Clavel criollo & Dianthus caryophyllus (a) & Prepares tea with flowers & Calms the cough \\
\hline Coquillo, Estropajillo & $\begin{array}{l}\text { Cuscuta corymbosa Ruíz \& Pavón } \\
\text { (a) }\end{array}$ & $\begin{array}{l}\text { Boil the plant and let stand, use the water for bathing } \\
\text { babies and children. Boiled plant is used as a scourer } \\
\text { to carve children. }\end{array}$ & Cure the "shock" and "aljorre" in children \\
\hline Dedo de niño & $\begin{array}{l}\text { Sedum rubrotinctum (Crassulaceae) } \\
\text { (a) }\end{array}$ & $\begin{array}{l}\text { Cut leaves and squeeze out the liquid until it contains } \\
\text { and apply a few drops in the ear or eye if it is the } \\
\text { case. }\end{array}$ & Eye and ear infection \\
\hline Espinosilla & $\begin{array}{l}\text { Loeselia mexicana (Lam.) } \\
\text { Brandegee (Uiwitz) (a) }\end{array}$ & $\begin{array}{l}\text { It cut } 3 \text { to } 4 \text { sprigs for } 1 / 2 \text { liter of water, taken in the } \\
\text { morning for } 3 \text { days. }\end{array}$ & Bile \\
\hline Espuela de caballero & Delphinium (b) & $\begin{array}{l}\text { Boil the branches and let stand, water used as "rinse" } \\
\text { during bath. }\end{array}$ & Postpartum bath \\
\hline Floripondio & Brugmansia candida Pers. (a) & $\begin{array}{l}\text { Fresh flower is crushed and puts a little alcohol, } \\
\text { smeared on the back. }\end{array}$ & Back pain \\
\hline Hierba del sol & Crusea longiflora (a) & $\begin{array}{l}\text { Boil two leaves in } 1 / 2 \text { liter of water and drink it. Note: } \\
\text { when the plant is freshly cut green but after boiling } \\
\text { turns a deep red color. }\end{array}$ & Fever \\
\hline Hierba dulce & Lippia dulcis Trev. (a) & $\begin{array}{l}\text { The leaves are boiled, allowed to cool a little and take } \\
\text { a little sweetened with honey. The leaves are boiled } \\
\text { and douches are made after childbirth or abortion. }\end{array}$ & $\begin{array}{l}\text { Cough, postpartum or post treatment } \\
\text { abortions. }\end{array}$ \\
\hline Hierba Maestra (ajenjo) & Artemisia absinthium L. (a) & Aqueous infusion of leaves, take as wáter. & $\begin{array}{l}\text { Bitter and to treat shock, bile, courage, } \\
\text { diabetes taste, and stomach pain. }\end{array}$ \\
\hline Huichin & Verbesina persicifolia DC. (a) & Whole plant is boiled and washed the infected part. & Wounds \\
\hline Ixtanzokpikxiuitl & & $\begin{array}{l}\text { A twig it is used in } 1 \text { liter of water, boiled and taken as } \\
\text { the pain persists. }\end{array}$ & Stomach ache \\
\hline Lengua de vaca & Rumex spp (a) & $\begin{array}{l}3 \text { leaves are boiled in } 1 / 2 \text { liter of water and taken for } 3 \\
\text { days. Two leaves as a poultice with lard and paper in } \\
\text { the abdomen. Boil two to three leaves of the plant dry } \\
\text { and mouthwashes are made. }\end{array}$ & $\begin{array}{l}\text { Diarrhea, courage, wounds, bile, } \\
\text { rheumatism. Reduce fever in children. Oral } \\
\text { diseases. Treatment of viral diseases. }\end{array}$ \\
\hline Malva & Malva parviflora L. (a) & $\begin{array}{l}\text { The whole plant is boiled and washed the infected } \\
\text { part. }\end{array}$ & Wounds. Infections \\
\hline Marrubio & Marrubium vulgare L. (a) & $\begin{array}{l}\text { The whole plant is boiled and washed the infected } \\
\text { part. }\end{array}$ & Wounds. Infections \\
\hline Matahuacal & & $\begin{array}{l}\text { Whole plant is boiled in } 1 \text { liter of water, let cool } \\
\text { slightly and put in place affected. }\end{array}$ & Acne \\
\hline Mazote & Bidens pilosa (a) & The leaves are boiled and taken as water. & stomach ailments \\
\hline Mejorana & Origanum majorana L. (a) & $\begin{array}{l}\text { Two or three twigs are cut into } 250 \mathrm{ml} \text {, to make them } \\
\text { in tea is taken warm. }\end{array}$ & Stomach ache \\
\hline Mirto & Salvia spp. (a) & $\begin{array}{l}\text { Boil leaves and use as a mouthwash after bathing. } \\
\text { Make corsages with sheets for "ramear" whole body. }\end{array}$ & $\begin{array}{l}\text { In "cold" diseases and oral diseases. To } \\
\text { scare }\end{array}$ \\
\hline Nogal & Juglans regia L. (a) & Infusion of leaves. Mouthwash. Rinses the scalp. & $\begin{array}{l}\text { Treatment of retracting the gingiva. Natural } \\
\text { dye for darkening hair. }\end{array}$ \\
\hline Poleo & Mentha pulegium L. (a) & $\begin{array}{l}2 \text { stripes are placed in } 250 \mathrm{ml} \text { of warm water and } \\
\text { taken }\end{array}$ & Indigestion. Stomach ache. \\
\hline Romero & Rosmarinus officinalis L. (a) & & $\begin{array}{l}\text { Treatment of "cold" diseases. Postpartum } \\
\text { bath. Hair Treatment (prevents hair loss). }\end{array}$ \\
\hline Sauco & Sambucos bipinnata (xomet) (a) & $\begin{array}{l}4 \text { to } 6 \text { leaves are boiled in } 1 \text { liter of water; it is taken } \\
\text { as hot as possible. }\end{array}$ & Threw up. Dizziness \\
\hline Toloache & Datura stramonium L. (a) & $\begin{array}{l}\text { Whole plant is boiled, allowed to cool a little and } \\
\text { make washes uterus. }\end{array}$ & $\begin{array}{l}\text { Wash uterus when you have cervical } \\
\text { cancer. }\end{array}$ \\
\hline Toronjil & Agastache mexicana (a) & Macerated in alcohol and take after meals & Aids digestion and stomach ailments \\
\hline $\begin{array}{l}\text { Vara milagrosa. Palito de } \\
\text { siete corazones }\end{array}$ & Haematoxylum brasiletto Karst. (a) & The bark is boiled and taken in tea or water weather & Depression \\
\hline
\end{tabular}

Table 1: Traditional uses and local names of Medicinal Plants from north region of Puebla. 
Citation: Jerezano Alberto VD, Ríos Saúl A, Tepancal-Gomez E, Salas-Mendosa E, Villanueva L, et al. (2016) Some Traditional Medicinal Plants of North Region from Puebla, Mexico: Uses and Potential Pharmacological Activity of Rumex spp. Nat Prod Chem Res 4: 223. doi:10.4172/23296836.1000223

Page 4 of 7

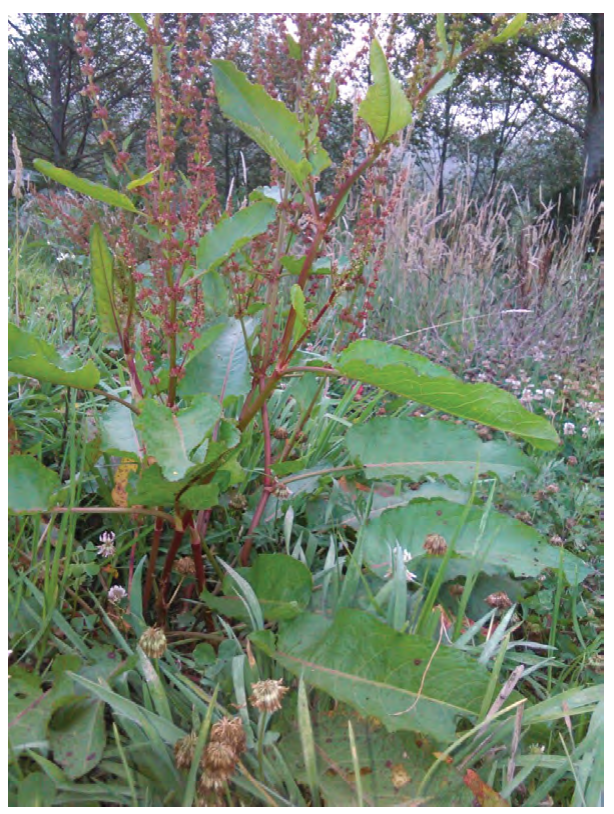

Figure 2: Rumex spp. Teziutlán Puebla.

\begin{tabular}{|c|c|c|c|}
\hline Scientific name & $\begin{array}{l}\text { Part of } \\
\text { the plant }\end{array}$ & Traditional use & Reference \\
\hline $\begin{array}{l}\text { Rumex patientia } \\
\text { Rumex scutatus }\end{array}$ & Leaves & $\begin{array}{l}\text { Antipyretic in traditional } \\
\text { medicine Turkish, anti- } \\
\text { inflammatory and analgesic. }\end{array}$ & {$[20,28]$} \\
\hline $\begin{array}{l}\text { Rumex acetosa } \\
\text { (Herba Rumicis } \\
\text { acetosa concis) }\end{array}$ & Whole & Tx. viral, reumathism. & {$[25,29]$} \\
\hline $\begin{array}{l}\text { Rumex scutatus } L . \\
\text { Rumex japonicus }\end{array}$ & Root & Hemorrhage, wounds. & [30] \\
\hline $\begin{array}{l}\text { Rumex acetosella, } \\
\text { acetosa, crispus, } \\
\text { vesicarius }\end{array}$ & Leaves & $\begin{array}{c}\text { Food (soups, sauces and } \\
\text { salads). }\end{array}$ & [31-33] \\
\hline $\begin{array}{c}\text { Rumex } \\
\text { hymenosepalus, } \\
\text { Rumex vesicarius }\end{array}$ & $\begin{array}{l}\text { Stems, } \\
\text { leaf and } \\
\text { roots }\end{array}$ & $\begin{array}{c}\text { Antioxidant, Antimycobacterial } \\
\text { in skin problems, } \\
\text { gastrointestinal disturbances } \\
\text { sore. }\end{array}$ & [34-36] \\
\hline Rumex dentatus & Whole & Antimicrobial. & [37] \\
\hline
\end{tabular}

Table 2: Traditional medicinal use parts of Rumex species.

\section{Traditional medicinal in north region of Puebla}

In the mountains north of Puebla, community commonly use Rumex spp as an astringent in treating diarrhea (indigestion) and externally to control bleeding and rashes, sores in the mouth. Mainly used THM in Teziutlán as an antipyretic in febrile episodes like poultices (confortativos), based on lard with paper in the abdomen of infants. They are also used in the treatment of rheumatism, jaundice and cooked the roots are used as a tonic. In infusions, dry leaf as antiseptic in mouthwashes for periodontal diseases (inflammatory processes of the gingiva) and bleeding. It has been used as a dietary supplement useful in the treatment of influenza and viral infections such as herpes repeated.

Food: The cooked "lengua de vaca" is used in most of the region as a companion to meat dishes (mole verde, eggs) or broth. Edible in salad, the leaves have a pleasant sour taste. Oxalic intoxication has at times been reported, mainly in children, due to the high oxalic acid content of the plants [21]. The edible variety is known as the language of elongated or pointed Cow (Rumex crispus) and is native to tropical America [27]. The genus Rumex is characterized by the accumulation of anthraquinones, naphthalens, flavonoids, stilbenoids, carotenoids, fenols, trans-resveratrol y rumexoid $[35,38,39]$. Table 3 shows the structures of some compounds isolated from Rumex species $[38,39]$.

Collects: Plants can be harvested from wild or cultivated plants. Rumex collection was conducted in a scientific manner of wild plants. In this first stage plant breeding is not controlled. Wild plant is where their demands are met shadow and light. Research has shown that light is a contributing factor to determine the amount of plant components as in the case of alkaloids in Datura spp light for training is not required [40]. It is also considered the altitude and climate (tempering with rains all year) from the northern region of the state of Puebla, which have a great influence on the population of plants. For Rumex spp, it grows adequately in Teziutlán and San Juan Xiutetelco, it shows that in Ayotoxco, which is another different altitude and amount of rain, is not Rumex spp. Soils differ from one another both in their physical and chemical properties. The soil is composed of mineral material, formed by the action of weathering of rocks, decaying organic matter or humus. In the case of the northern region of the state of Puebla soil type is andosol predominantly volcanic soil dark and very porous. The time when each plant is collected generally has considerable importance, since the amount, and sometimes the nature of the active ingredients, are not constant throughout the year. Betts and Fairbair showed that the content of C-heterosides, O-heterosides and free anthraquinones in the developing leaves of Rhamnus purshiana it fluctuates markedly throughout the year [41]. An investigation of changes in the consituyentes in the collected plants Rumex spp in different locations and periods of vegetation revealed that the total amount of phenolic compounds are increased through the cycle of the plant, but decreases in samples of greenhouses (controlled) compared with those observed in the field samples (wild) [42]. Aerial parts of Rumex spp, free fresh leaves dew or attacked by insects, were collected.

Dryng: The drying process can be slow or fast. When it is necessary to stimulate the enzymatic action, drying should be slow, at moderate temperatures. If it is necessary to avoid enzymatic action, drying should be started as soon as possible after collection, as in the case of essences [40]. With the leaves of Rumex spp., the drying was performed outdoors without artificial heat for weeks to ensure maximum enzymatic action.

Trituration: The dried leaves of Rumex spp were grinded in food processor Braun Multi quick to a fine powder.

Exhaustive extraction: Maceration process was chosen for the collection of the active ingredients (prolonged infusion) with solvents of different polarities followed by percolation (addition of fresh solvent to replace the solvent has passed up through the ground powder) [43]. Initially the medicinal plant was extracted with a nonpolar solvent (hexanes), followed by exhaustive extraction with AcOEt and EtOH. Excess solvents was removed under reduced pressure to obtained dark solid (Hexanoic extract) and dark oil (AcOEt and EtOH extract), the yields show in Table 4 .

\section{Conclusion}

Summarizing these information, the use of medicinal plant comprising highly complex mixtures of up to several hundred compounds in Traditional Herbal Medicinal (THM). The medicinal plants are very economical to production and has pharmacological activity potential. THM, in full, is considered as "primary medicine" with botanical qualities to "help" or "protect." Therapists use medicinal plants, depending on the disease (cold or hot) in the case that the plants are used alone or in combination with other herbs to prepare plasters, poultices, medicinal teas. Despite its historical and cultural 
Citation: Jerezano Alberto VD, Ríos Saúl A, Tepancal-Gomez E, Salas-Mendosa E, Villanueva L, et al. (2016) Some Traditional Medicinal Plants of North Region from Puebla, Mexico: Uses and Potential Pharmacological Activity of Rumex spp. Nat Prod Chem Res 4: 223. doi:10.4172/23296836.1000223

Page 5 of 7

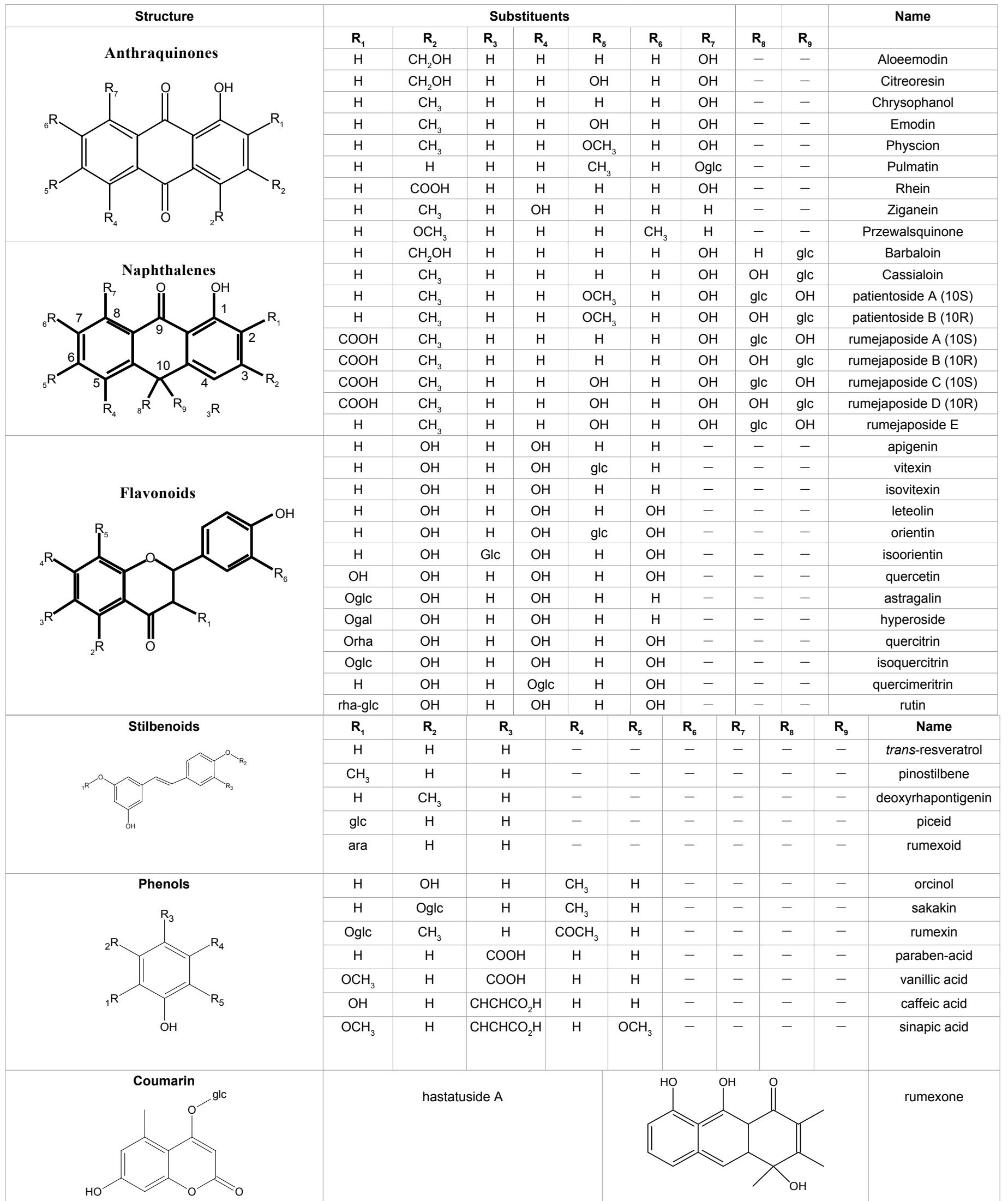

Table 3: Structures of some compounds isolated from Rumex species. 
Citation: Jerezano Alberto VD, Ríos Saúl A, Tepancal-Gomez E, Salas-Mendosa E, Villanueva L, et al. (2016) Some Traditional Medicinal Plants of North Region from Puebla, Mexico: Uses and Potential Pharmacological Activity of Rumex spp. Nat Prod Chem Res 4: 223. doi:10.4172/23296836.1000223

Page 6 of 7

\begin{tabular}{|c|c|}
\hline Rumex Leaf Extract & Yield $^{\text {a }}$ \\
\hline Hex (dark solid) & 0.48 \\
\hline AcOEt (dark oil) & 2.16 \\
\hline EtOH (dark oil) & 0.40 \\
\hline
\end{tabular}

12. Widdicombe JG, Ernst E (2009) Clinical cough V: complementary and alternative medicine: therapy of cough. Handb Exp Pharmacol : 321-342.

13. Shrivastava R, Pechadre JC, John GW (2006) Tanacetum parthenium and Salix alba (Mig-RL) combination in migraine prophylaxis: a prospective, openlabel study. Clin Drug Investig 26: 287-296.

aThe yield is given in percentage (\%)

Table 4: Yields of Hex, AcOEt and EtOH extracts of leaves from Rumex spp the region Teziutlán, Puebla.

importance, the "traditional" use of plants has decreased. Further preclinical and clinical studies and investigations are needed to clarify the potential antipyretic action of extracts from Rumex spp, safety and efficacy therapeutic in the community practice as well as purification, isolation and elucidation of the components from extracts obtained.

\section{Acknowledgements}

We are grateful to MD. Esperanza Morales Pérez, Principal DGPI-BUAP PhD. Hortencia Chavez Oseki, Principal School Stomatology-BUAP, PhD. Jaime Meneses Guerra, Principal School Medicine-BUAP, MD. María de la Luz Bonilla Luis, Principal School Nursing-BUAP, MD. Vicente Andrés Martínez Valdés, Principal School Psychology-BUAP; Dr. Rodolfo Martínez Fernández, Director of Teaching and Research; Dr. José Gilberto Romero Martínez, Head of the Department of Health Research; Lic. Ma. Del Socorro Adame, Ma. Ilda Parga Parga, Operational State Coordination of Traditional Medicine; MD. Verónica Hernández Escobar, Coordinator Traditional Medicine Module from Ayotoxco, Veracruz; Biol. Analí Santos García, Coordinator Traditional Medicine Module from Xalacapan, Zacapoaxtla, Puebla, and especially to Therapists of module for encouragement and knowledge during the research. Thank to "La Ciencia en tus manos", "Jóvenes Investigadores Otoño VII" programs from VIEP-BUAP (Vicerrectoría de Investigación y Estudios de Posgrado), Amairani del Carmen Sanchez Perez, Alexis Villa Hernandez and Diego Ivan Sanchez Vazquez. J. A. gratefully acknowledges to PRODEP-SEP ("Programa para el Desarrollo Profesional Docente, para el tipo superior") for financial support.

\section{References}

1. World Health Organization (2003) Available Online on: http://www.who.int/ mediacentre/factsheets/2003/fs 134/en/.

2. Li C, He J, Tao L, Wang H, Jiang J, et al. (2013) Acaroid mite infestations (Astigmatina) in stored traditional Chinese medicinal herbs. Systematic \& Applied Acarology 18: 401-410.

3. Dold ML, Cocks $P$ (2006) The angel in the gourd: ritual, therapeutic, and protective uses of tobacco (nicotiana tabacum) among the tzeltal and tzotzil maya of Chiapas, Mexico. Journal of Ethnobiology 26: 60-81.

4. Groark KP (2010) Cultural significance of biodiversity: The role of medicinal plants in urban african cultural practices in the eastern cape, South Africa. Journal of Ethnobiology 30: 5-30.

5. Philander $L$ (2012) Hunting Knowledge and gathering Herbs: Rastafari bush doctors en the western cape, South Africa. Journal of Ethnobiology 32: 134-156.

6. Silva LR, Pereira MJ,Azevedo J, Gonçalvesa RF, Valentão P, et al. (2013) Glycine $\max (\mathrm{L}$.) Merr., Vigna radiata L. and Medicago sativa L. sprouts: A natural sprouts: A natural source of bioactive compounds. Food Research International 50: 167-175

7. Seeff LB, Curto TM, Szabo G, Everson GT, Bonkovsky HL, et al. (2008) Herbal product use by persons enrolled in the hepatitis $C$ Antiviral Long-Term Treatment Against Cirrhosis (HALT-C) Trial. Hepatology 47: 605-612.

8. Strader DB, Bacon BR, Lindsay KL, La Brecque DR, Morgan T, et al. (2002) Use of complementary and alternative medicine in patients with liver disease. Am J Gastroenterol 97: 2391-2397.

9. Boznkov PV, Brukhin, VB, Moleva LR, Filonova LH, Grakhov VP, et al (1999) Proliferative activity of callus cultures of Taxus baccata $L$. in relation to anticancer diterpenoid taxol biosynthesis. Biotechnology Letters 18: 1309-1314.

10. Yegdaneh A, Sadeghi-aliabadi H (2013) Taxol and Related Compunds. Natural Products 101: 3159-3171.

11. Davis K (2016) Galantamine for Alzheimer's disease and Alzheimer's disease with cerebrovascular Disease. Practical Pharmacology for Alzheimer's Disease 1149: 35-61.

14. Farppqui A (2012) Beneficial Effects of Ginkgo biloba in Neurological Disorders, New York. Springer Science+Business Media, pp: 237-270.

15. Moreno Botello MC (1997) La botánica en Puebla. Elementos 4: 45-55.

16. Martinez-Moreno D, Alvarado-Flores R, Mendoza-Cruz M, Basurto-Peña $F$ (2006) Plantas Medcinales de Cuatro Mercados del Estado de Puebla, Mexico. Bol Soc Bot Mex 79: 79-87.

17. INEGI (2009) Prontuario de informacio'n geogra'fica municipal de los Estados Unidos Mexicanos Teziutla'n. Puebla Clave geoestadi'stica 21: 174.

18. Muñoz-Hernandez A, Moron MA, Aragon A (2008) Coleoptera scarabaeoidea de la Región de Teziutlán, Puebla, Mexico. Acta Zoologica Mexicana 24: 57-78.

19. Zarrazaga M (2004) Hospitales integrales con medicina tradicional. Memorias del Cuarto Seminario Nacional y el Segundo Internacional Recursos Fitogenéticos de Plantas medicinales, aromáticas y condimentarias Palmira Colombia.

20. Süleyman H, DemirezerL, Kuruüzüm A, Banoglu Z, Göcer F, et al. (1999) Antiinflammatory effect of the aqueous extract form Rumex patientia L. roots. Journal of Ethnopharmacology 65: 141-148.

21. Farré M, Xirgu J, Salgado A, Peracaula R, Reig R, et al. (1989) Fatal oxalic acid poisoning from sorrel soup. Lancet 2: 1524.

22. Gautam R, Srivastava A, Jachak S (2011) Simultaneous determination of naphtalene and anthraquinone derivatives in Rumex nepalensis Spreng roots by HPLC: Comparison of different extraction methods and validation. Phytochemical Analysis 22: 153-157.

23. Mekonnen T, Urga K, Engidawork E (2010) Evaluation of the diuretic and analgesic activities of the rizomes fo Rumex abysicinicus Jacq in mice. Journal of Ethnopharmacology 127: 433-439.

24. Derksen A, Hensel A, Herrmann F, Schmidt TJ, Ehrhardt C, et al. (2014) 3-OGalloylated Procyanidins from Rumex acetosa L. Inhibit the Attachment of Influenza A Virus. PLOS ONE 9: 1-13

25. Gescher K, Hensel A, Hafezi W, Derkesen A, Jühn J (2011) Oligomeric oranthocyanidins from Rumex acetosa L. inhibit the attachment of herpex simplex virus type-1. Antiviral Research 89: 9-18.

26. Vasas A, Orbán-Gyapai O, Hoffman J (2015) The Genus Rumex Review of traditional uses, phytochemistry and pharmacology. Journal of Ethnopharmacology 175: 198-228.

27. Rechinger KH (1990) Rumex subgen. Rumex sect. Axillares (Polygonaceae) in South America. Plant Systematics and Evolution 172: 151-192.

28. Cakilcioglu U, Sengün MT, Türkoglu I (2010) An ethnobotanical survey of medicinal plants of Yazikonak and Yurtbasi Districits of Elazig Province Turkey. Journal of Medicinal Plants Research 4: 567-572.

29. Gairola S, Sharma J, Bedi YS (2014) A cross-cultural analysis of Jammu, Kashmir and Ladakh (India) medicinal plant use. Journal of Ethnopharmacolgy 155: 925-986.

30. Zee OP, Kim DK, Kwon HC, Lee KR (1998) A new epoxynaphthoquinol from Rumex japonicus. Archives of Pharmal Research 21: 485-486.

31. Alfawaz MA (2006) Chemical composition of hummayd (Rumex vesicarius) grown in Saudi Arabia. Journal of Food Composition and Analysis 19: 552-555

32. Pardo-de-Santayana M, Tardío J, Morales R (2005) The gathering and consumption of wild edible plants in the Campoo (Cantabria, Spain). International Journal of Food Science and Nutrition 56: 529-542.

33. Polat R, Selvi S, Cakilcioglu U, Acar M (2012) Investigation of ethnobotanical aspect of wild sold in Bingöl (Turkey) local markets. Biological Diversity and Conservation 5: 155-161.

34. VanderJagt TJ, Ghattas R, VanderJagt DJ, Crossey M, Glew RH (2002) Comparison of the total antioxidant content of 30 widely used medicinal plants of New Mexico. Life Science 70: 1035-1040.

35. Rivero-Cruz I, Acevedo L, Guerrero J, Martinez S, Bye R, et al. (2005) Antimycobacterial agents from selected Mexican medicinal plants. Journal of Pharmacy and Pharmacology 57: 1117-1126. 
Citation: Jerezano Alberto VD, Ríos Saúl A, Tepancal-Gomez E, Salas-Mendosa E, Villanueva L, et al. (2016) Some Traditional Medicinal Plants of North Region from Puebla, Mexico: Uses and Potential Pharmacological Activity of Rumex spp. Nat Prod Chem Res 4: 223. doi:10.4172/23296836.1000223

Page 7 of 7

36. Khan TH, Ganaie MA, Siddiqui NA, Alam A, Ansari MN (2014) Antioxidant potential of Rumex vesicarius L.: in vitro approach. Asian Pac J Trop Biomed 4: 538-544.

37. El-Shahaby O, El-Zayat M, Salih E, El-Sherbiny IM, Reicha FM (2013) Evaluation of Antimicrobial Activity of water infusion plants-mediated Silver Nanoparticles. Nanomedicine \& Nanotechnology 4: 1-7.

38. Kerem A, Regev-Shoshani G, Flaishman M, Sivan L (2003) Resveratrol and two monomethylated stilbenes from israeli Rumes bucephalophorus and their antioxidant potencial. Journal of Natural Products 66: 1270-1272.

39. Kerem A, Bilkis I, Flaishman M, Sivan L (2006) Antioxidant activity and inhibition of alfa-glucosidase by trans-resveratrol, piceid and a novel trans-stilbene from the roots of Israeli Rumex bucephalophorus L. Journal of Agricultural and Food Chemistry 54: 1243-1247.

40. Evans WC, Trease GE (1977) Farmacognosy, México. Compañia Editorial Continental SA.

41. Betts T and Fairbairn J (1964) The significance of antracene derivatives to the living plant of Rhamnus purshiana DC. Planta Medica 12: 64-70.

42. Guerra L, Pereira C, Andrade PB, Rodrigues MA, Ferreres F, et al. (2008) Targeted metabolite analysis and antioxidant potential of Rumex induratus. Journal of Agricultural and Food Chemistry 56: 8184-8194.

43. Ciria VO (1995) Fundamentos de Fitoquímica, México. Trillas. 